\title{
Chapter 1 \\ Organic Waste Composting Through Nexus Thinking: Linking Soil and Waste as a Substantial Contribution to Sustainable Development
}

\author{
Hiroshan Hettiarachchi, Johan Bouma, Serena Caucci, and Lulu Zhang
}

\begin{abstract}
This introductory chapter explains why organic waste composting is considered as one of the best examples to demonstrate the benefits of nexus thinking. Current literature is rich with information covering various aspects of composting process. However, it mainly represents two distinct fields: waste from the management point of view and soil/agriculture from the nutrient recycling point of view. It is hard to find information on how these two fields can benefit from each other, except for a few examples found within large agricultural fields/businesses. A policy/institutional framework that supports a broader integration of management of such resources is lacking: a structure that goes beyond the typical municipal or ministerial boundaries. There is a clear need to address this gap, and nexus thinking can help immensely close the gap by facilitating the mindset needed for policy integration. Good intention of being sustainable is not enough if there is no comprehensive plan to find a stable market for the compost as a product. Therefore, the chapter also discusses the strong need to have a good business case for composting projects. Composting can also support achieving the Sustainable Development Goals (SDGs) proposed by the United Nations. While directly supporting SDG 2 (Zero hunger), SDG 12 (Responsible consumption and production), and SDG 13 (Climate action), enhanced composting practices may also assist us reach several other targets specified in other SDGs. While encouraging waste composting as a sustainable method of waste and soil management, we should also be cautious about the possible adverse effects compost can have on the environment and public health, especially due to some non-traditional raw materials that we use nowadays such as wastewater sludge and farm manure. Towards the end, we urge for the improvement of the entire chain ranging from waste generation to waste collection/separation to com-
\end{abstract}

H. Hettiarachchi $(\bowtie) \cdot$ S. Caucci $\cdot$ L. Zhang

United Nations University (UNU-FLORES), Dresden, Sachsen, Germany

e-mail: hiroshanh@gmail.com; caucci@unu.edu; lzhang@unu.edu

J. Bouma

(Formerly) Wageningen University, Wageningen, The Netherlands

e-mail: johan.bouma@planet.nl 
post formation and, finally, application to soil to ensure society receives the maximum benefit from composting.

Keywords Compost $\cdot$ Municipal solid waste $(\mathrm{MSW}) \cdot$ Nexus thinking $\cdot$ Nutrients - Organic waste $\cdot$ Soil organic matter $(\mathrm{SOM}) \cdot$ Sustainable Development Goals (SDGs) · Waste management

\section{Background}

Composting is a natural process of biological decomposition and stabilisation of organic waste (Oppliger and Duquenne 2016; Dollhofer and Zettl 2017). The nutrient-rich final product, that can be applied to land as soil fertiliser or stabiliser, offers significant benefits to agroecological systems as it combines environmental protection with sustainable agricultural production (Thanh et al. 2015; Román et al. 2015; Mbuligwe et al. 2002). The improvement of soil properties is a major benefit of compost application (Brändli et al. 2007).

Composting has also been gaining increasing attention as an alternative way of waste processing. In addition to the organic fraction of municipal solid waste (MSW), it is now also being adapted for treatment of various other types of organic waste such as farm manures, sewage sludge, and industrial sludge (Otoo and Drechsel 2018; Azim et al. 2018; Barker 1997). Indeed, the composting process has the ability to reduce pathogenic bacteria, viruses, and parasites in such waste material, which could otherwise pose a health risk. Although pathogens cannot be eliminated completely via composting, the presence of pathogens in compost is lower than in livestock manures (Wéry 2014).

In the above context, organic waste composting helps us to be more sustainable with how we manage our environmental resources. Nutrient recycling embedded in the concept of composting supports the idea of transitioning to a circular economy, which is currently being discussed in many international circles. There is also another international dialogue currently occurring on the developmental agenda put forward by the United Nations in 2015, which comprises of 17 goals to be achieved by 2030, i.e. Sustainable Development Goals (SDGs) (UN 2015a). As we discuss later in this chapter, organic waste composting directly addresses a few SDGs in addition to partially supporting several others.

Despite how interesting it sounds as an idea and the tremendous potential it offers from the circular economic point of view to achieve the SDGs, organic waste composting is not popular enough yet. Among many reasons, two stand out more prominently. One reason is the disconnect between the agricultural sector where compost is applied and the waste management sector where the bulk of raw material originates from. The policies and institutional structures we have today do not 
necessarily provide any space for the integrated management of resources (Hettiarachchi and Ardakanian 2016a). The other prominent reason is the lack of a strong business case. Many composting projects from around the world have failed due to the lack of the same (Hettiarachchi et al. 2018; Otoo and Drechsel 2018). Good intention of being sustainable itself is not enough if there is no comprehensive plan to find a stable market for the compost as a product. It is unfortunate that compost projects fail, while there is still a clear need and a reasonable demand for them in the agricultural sector. A policy framework that allows for broader integration of management of such resources, that goes beyond typical municipal or ministerial boundaries, is lacking (Hettiarachchi and Ardakanian 2016a; Subramanian et al. 2019).

The primary objective of this book is to shed light on the reasons behind the above gaps and introduce the potential of nexus thinking as a way forward. Nexus thinking facilitates the mindset needed for policy integration to promote the integrated management of resources (Hettiarachchi and Ardakanian 2016a; Subramanian et al. 2019). How we may bridge the gaps existing between soil and waste management through nexus thinking is elaborated in a later part of this chapter. Some emerging trends observed in the field of composting, both positive and negative, also demand attention. Among others, there is currently a growing concern about the spread of antibiotic resistance and its impact on humans and animals. The role played by the composting industry, in this regard, warrants a discussion. Compost made from municipal solid waste and poultry manure/litter may also contribute to the spread of pollutants of emerging concerns, including antimicrobial resistance determinants, micro- and nanoplastics, and organic pollutants.

In this context, the objective of this chapter is to introduce the entire book to set the scene for a deeper discussion. In the next sections, we present the abovementioned information in greater detail.

\section{Compost: A Sustainable Product for Soil Enrichment}

There is an escalating concern about soil and land degradation, as global demands for food, water, energy, and raw materials continue to grow at unprecedented rates. The lack of success in meeting these demands can easily cause adverse ripple effects in other issues important for humanity such as hunger, poverty, peace, migration, and well-being. The Global Land Outlook (UNCCD 2017) estimates that one third of the global land surface is severely degraded, which has negative impacts on the well-being of at least 3.2 billion people across all continents. This results in losses of biodiversity and ecosystem services amounting to an economic loss of about $10 \%$ of the world's annual gross product in 2010. In the European Union, soil degradation causes an annual loss of 2.46 megagrams of soil per hectare each year $(\mathrm{Mg} /$ ha.year) from erosion-prone lands, equivalent to an area the size of Berlin to a depth of $1 \mathrm{~m}$ (Panagos and Borrelli 2017). Beyond Europe, conditions are worse: erosion rates in South America (3.53 Mg/ha.year), Africa (3.51 Mg/ha.year), and Asia 
(3.47 Mg/ha.year) are even higher (Borrelli et al. 2017). In addition, low soil organic matter (SOM) is also becoming a concern. For example, $45 \%$ of European soils now have low SOM, mostly in Southern Europe, but also in areas of France, the UK, and Germany (Jones et al. 2012). This negatively affects soil quality as the water holding capacity is reduced, as are soil structural stability and the nutrient adsorption potential. To feed an ever-increasing population while adapting to climate change, protecting and restoring soils must be mandatory to maintain ecosystem services (Bastida et al. 2015).

There are several ways to overcome the long list of challenges from land degradation to soil losses and loss of biodiversity. One of the restoring approaches to recover and mitigate soil degradation is by preserving and enhancing SOM content in soils. The increase of SOM enhances the aggregation of soil particles, thus improving aggregate stability and soil structure (Apostolakis et al. 2017). Stable soil aggregates reduce the risks of soil surface sealing and associated surface run-off formation, minimise soil erosion, promote water infiltration, and enhance the soil water retention capacity (Martínez-Blanco et al. 2013; Lado et al. 2004). Additionally, increasing SOM mitigates global warming through sequestering carbon in soils and reducing greenhouse gas emission. It is important to state that the French proposal, suggesting an average increase of SOM by only $0.04 \%$ is now part of the Paris climate agreement of 2015 (Initiative 4 pour 1000 2018). Increased SOM also benefits the soil microbiome and biodiversity, which, in turn, facilitates better nutrient supply for plants and suppression of soilborne diseases (Cesarano et al. 2017; Martínez-Blanco et al. 2013).

The key question now is how we can increase SOM. Organic manure is widely used, but its quantity and quality are inadequate in many parts of the world. Green manuring - growing alfalfa and other crops that bind nitrogen through microbiological processes - is an option, but as a solution not in the least practical, because it does not commercially allow more attractive crops to be grown at the same time. Leaving crop residues on the land is another measure to increase SOM, but - as in the case of organic manure - its quantity is too limited. Even though there might not be one perfect solution, century-long experiences humanity had with composting suggest that compost might be the sustainable solution to increase SOM.

Compost is considered invaluable for soil scientists, land managers, and farmers, not necessarily in terms of monetary value, but due to the richness in composition with organic materials, multiple nutrients (e.g. N, P, K), microbiomes, and water that are vital for land-based production. This makes compost an even more attractive option for the purposes of land restoration. Some of these soil-focused benefits are highlighted in the case studies from Tanzania presented in Chaps. 5 and 8 and the one from Sri Lanka in Chap. 4. Yields of fields fertilised with compost were measured, but the associated soil processes, as a function of natural soil moisture regimes, were not identified which makes extrapolation of results difficult. From this perspective, soil scientists and land management specialists have a task to fulfil, i.e. to obtain optimal compost products that can restore soil and make use of the nutrients and water pool properties to generate specific environmental and socioeconomic benefits (Martínez-Blanco et al. 2013; Onwosi et al. 2017). 


\section{Composting: A Sustainable Method of Managing Organic Waste}

Organic wastes commonly comprise food wastes, garden wastes, agricultural wastes, and some process residues. As the World Bank estimates, the per capita MSW generation has now reached $0.74 \mathrm{~kg} /$ day and is expected to increase by another $70 \%$ by 2050 (Kaza et al. 2018). It is important to understand that the largest fraction is almost always the organics, which can vary from $27 \%$ in OECD countries to $62 \%$ in East Asia and the Pacific (World Bank 2012). These numbers provide some perspective to the volume of organic waste that we produce and the difficulties we face in managing it. Undoubtedly, the effective management of organic solid waste is essential to mitigate environmental and socioeconomic risks of solid wastes.

From the management point of view, organic waste is an "issue" that we need to address timely, and there are standard engineering solutions such as landfilling or incineration that we can use. Organic waste is potentially an even bigger "issue" than the other types of waste, due to the damage it can cause to the environment and public health, if not managed properly (Hettiarachchi et al. 2018). However, from the sustainability point of view, organic waste is not an issue, rather it is a resource. Several alternative methods have been proposed to capitalise on the resource point of view of organic waste (Otoo and Drechsel 2018). Among these options, composting has gained wide attention because of low operating costs and high environmental compatibility (Onwosi et al. 2017). Some of these key aspects of composting as a waste management option are particularly highlighted in the two case studies from Colombia and India (Chaps. 2, 3, and 7). Moreover, in comparison to other approaches, composting is also attractive as it is one of the oldest, best-known, and well-established processes (Martínez-Blanco et al. 2013).

The impact compost makes on society goes far beyond its simplicity and meets many distinct objectives across sectors. For example, in MSW management, composting also helps to shrink the waste volume, which would otherwise occupy landfill space. From the viewpoint of resource recovery, which is an important component in the waste management pyramid (in importance order: waste prevention and minimisation, reusing, recycling, valorisation, and final disposal), the nutrient recycling aspect of composting makes it a very sustainable method of managing organic waste. From the environmental, economic, and social perspectives, composting turns organic wastes into a product (compost) useful for agricultural activities and soil restoration which is carbon-, water-, and nutrient-rich and free of most pathogens. Thus, nutrient recycling through composting addresses the well-known three pillars of sustainability: the society, the economy, and the environment. 


\section{Bridging the Gaps Through Nexus Thinking}

The discussion above leads to one solid conclusion: composting is a sustainable method of managing organic waste and the final product - compost - is a sustainable way to enrich soils. Considering the large size of the global agricultural industry and the large volume of organic waste we produce, the two concepts should technically complement each other to create a very successful and large composting industry. However, we know that this is currently not the case. To address this, we need to look at the underlying reasons that have been briefly mentioned earlier: the disconnect between the soil and waste fields and the lack of a better business case.

The disconnect between the soil/agricultural sector and the waste sector is due to how the two sectors traditionally evolved independently. In general, MSW is handled by municipalities, while agricultural businesses are mainly in the private sector. Those who are involved in the two sectors are also trained professionally in two different settings. The same trend can be seen in the research and academia as well. Current literature on composting is rich with many journal articles, conference papers, and book chapters and also in the popular press, covering various aspects. However, these articles (and the authors) almost always represent only one side of the story: it is either about waste from the management point of view or about soil/ agriculture from the nutrient recycling perspective. It is rare to find information on how these two sectors can benefit from each other.

Many composting businesses have suffered from lack of a better business case. If we ask a compost manufacturer, the answer would more likely be about the absence of a steady/profitable market for the product. It is true that compost making cannot survive as a business if the products cannot find a steady market. This is where most compost projects have failed in the past. If we ask farmers (in developing countries) why they are not interested in compost, the most probable answer would be that the mineral/chemical fertiliser is cheaper than compost due to government subsidies (ADB 2011). No one can expect farmers to give up on mineral/ chemical fertilisers to buy more expensive compost, just because it is a more sustainable option. This implies the clash of different policies: while there are policies encouraging municipalities to be more sustainable in the ways they handle waste, other government policies have created fertiliser subsidies with the intention of helping farmers.

The quality of compost made from organic waste has also been raised as an issue. Implementing source separation is the simplest answer (Hettiarachchi et al. 2018). However, composting businesses are not able to implement any collection policies as it is the responsibility of the municipality. This tells us how important it is to have policies and collaborations that go beyond the traditional boundaries. Sectorial thinking does not help much as exhibited by the low volume of compost production compared to the sheer volume of organic waste we produce. Now the questions that remain are: who should take the lead in making compost out of organic waste? Is this an agricultural issue, or should it be up to the local municipality? Or else, should this be a topic for a wider discussion on environmental resources management? Any 
plan that involves both the agricultural and business communities in close interaction with the local and wider policy arena would certainly have the greatest potential to succeed.

Here, we can benefit from the emerging concept of nexus thinking in managing environmental resources. What nexus thinking promotes is a higher-level integration that goes beyond the disciplinary boundaries (Hettiarachchi and Ardakanian 2016a). One excellent example is wastewater recycling for agricultural irrigation. From the resource point of view, wastewater helps alleviate the supply issues faced by the water sector and water demand issues in the agricultural sector. This importance of wastewater recycling as a nexus example has been widely discussed before by UNU-FLORES in other publications (Hettiarachchi and Ardakanian 2016b, 2018). The topic of our current discussion - compost - is another very fitting example that can benefit from nexus thinking. Like the wastewater example, the compost chain too starts in the waste sector. But the final product feeds into the soil/agriculture and food sectors. Through its water retention properties, compost also contributes to the water sector by offering water savings in agricultural irrigation as well as higher purification of percolating water due to a higher soil adsorption capacity.

The above examples showcase how nexus thinking leads to a higher-level integration of environmental resources management. However, the beauty of the concept lies in its ability to force us to think through the policy infrastructure. Policy integration is a must for nexus thinking to be beneficial. It is not easy, but not impossible either, as shown in Chap. 2 with the Cajicá example. Through a participatory approach, the municipality of this small city in Colombia was able to involve all stakeholders to reinvent its policy structure to establish a successful composting programme in a few years. A similar approach is also showcased in Chap. 4 and in the Utilization of Organic Waste for Improvement of Agricultural Productivity (UOWIAP) Project from Accra, Ghana, presented in Chap. 6.

This illustrates an important emerging aspect of nexus thinking. Close cooperation and interaction among stakeholders involved in waste collection, compost formation, and its application in soils is essential. Interdisciplinarity brought by the stakeholders shows us how important it is to take a similar path in research, too, and conduct interdisciplinary research in close interaction with all stakeholders. This becomes increasingly important in the twenty-first century where information should be widely available and accessible and affects people's reaction to results and conclusions presented by scientists and policymakers alike (Bouma 2019a). Rather than studying "their" problems in a detached manner, it is more beneficial to tackle the problems thinking that they are "our" problems (Bouma 2018). Creating a feeling of ownership among stakeholders is crucial to achieve effects of practical significance. 


\section{Composting in the Sustainable Development Agenda}

We are now being challenged by the implications of global changes. The population explosion that will result in an estimated ten billion people by the middle of the century (UN 2017), climate change, water scarcity, land degradation, and overall decline of environmental quality are some of the notable ones. Although we feel it now, the need for remedial action for the same challenges has long been recognised. In 1987 the iconic Brundtland Report on Our Common Future introduced the concept of sustainable development, emphasising the need to not only consider economic aspects but also social and environmental aspects when defining future actions aimed at maintaining a vital global environment (WCED 1987). The concept of sustainable development has, however, remained rather abstract in the international arena for a decade or so, until the Millennium Development Goals were unveiled in the year 2000 (UN 2015b). The concept has been further improved when the 17 Sustainable Development Goals (SDGs), that apply to the entire world, were defined in 2015. The SDGs do not present lofty, abstract goals as they have been formally adopted by 135 countries accepting the obligation to satisfy specific targets and indicators by 2030. Although SDGs are brought into discussions in Chaps. 5 and 6 of this book, it is apparent that the concept has not yet been completely internalised by the stakeholders. This is also evident from the fact that soil scientists have not been engaged with defining targets and indicators for the various SDGs (Bouma 2019a). Active engagement by all parties is important as we approach the year 2030 in only a decade from now.

Achieving the SDGs by 2030 is undoubtedly a very ambitious goal. The success of achieving them will surely depend not only on innovative solutions but also new thinking. It is also important to note the limitations we have in the traditional, individual scientific disciplines, in offering any comprehensive practical approaches that can result in achieving any of the SDGs (Bouma 2014; Keesstra et al. 2016). As previously discussed, nexus thinking, however, provides a platform for such practical solutions to prosper. Taking the resource perspective into account, the concept of integrated management of Water-Soil-Waste, put forward by UNU-FLORES, offers us a route to overcome some of these SDG challenges. Organic waste composting is an example highlighting the utility of nexus thinking to help us achieve the SDGs.

Enhanced composting efforts directly support the task of achieving SDG 2 (Zero hunger), SDG 12 (Responsible consumption and production), and SDG 13 (Climate action). Through its relevance to agriculture, nutrient recycling, and waste (converting a greenhouse gas emitter into a solution), the direct relevance of composting to above SDGs is readily understood. In addition, it will also help us partially address numerous other goals, which we might not instantly recognise the importance of until we look at the list of targets each goal carries. For example, SDG 6 (Water and sanitation) has a target (6.4) to increase water use efficiency. Compost, which is known for its ability to improve the water retention capacity of soils, can help us address this target from the agricultural water use efficiency point of view. SDG 11 (Sustainable cities and communities) has a target (11.6) about municipal and other 
waste management to minimise the adverse impact on the environment. SDG 15 (Life on land) is another example that has a target (15.3) to restore degraded land and soil. SDG 17 (Partnerships for the goals) encourages promoting effective public, public-private, and civil society partnerships in one target (17.17). Composting is one good example where such partnerships already function very well, especially when the MSW management lies in the public sector and the usage of compost mainly happens in the private sector, while compost is currently made by organisations representing all of the above sectors.

As mentioned above, compost offers a unique and adequate source of carbon to increase SOM. However, the chain from waste generation, compost preparation, and application to soils is long and complex and involves many actors, each of which often has contradicting interests and demands. New approaches always offer resistance, in this case, traditional land users who find it hard to change existing practices. Composting has a problem in that it has a negative connotation to many people, which is strengthened when animal manure (or even human excreta in some cases) with pathogens and industrial waste with heavy metals are part of the process. How do we overcome these often psychological barriers in integrating compost into agricultural production systems? So far, we have discussed how composting can help us achieve the SDGs. In fact, the SDGs themselves can be used in return to overcome psychological barriers discussed above and make compost popular as a solution. There are many awareness-raising campaigns about the SDGs, their impact, and how to achieve them. Such campaigns could, when well-designed, become effective information channels serving the composting industry.

Recently, the concept of soil security has also been advanced in soil science research (Field et al. 2017) based on the 5Cs: Condition (actual condition of the soil), Capability (what can be achieved with improved management), Capital (how the soil compares with others), Connectivity (connection with stakeholders and the policy arena), and Codification (role of soils in laws and regulations). There is a clear link between soil security and not only the SDGs (Bouma 2019b) but also with the Water-Soil-Waste Nexus as discussed in this book. The soil security concept puts the soil in a wider societal context, as also expected from the integrated management of Water-Soil-Waste.

\section{Emerging Trends: New Opportunities Versus New Challenges}

New trends related to composting have been recognised lately: some are positive, and others might be alarming. Positive trends include the small but relatively steady demand for compost caused by the popularity of organic farming (USADA 2011), increased awareness of the role of waste in a circular economy (Hettiarachchi 2018), push for use of crop residue for composting rather than burning (Subramanian et al. 2019), and increased use of non-traditional raw material to make new compost 
products through various co-composting technologies (as described in Chaps. 9 and 10 in the book). The use of various non-traditional raw materials, seemingly a positive trend, might have inadvertently opened a Pandora's box for the composting industry from the public health perspective as further described in the case study from Sri Lanka in Chap. 4. While encouraging introducing organic waste composting as a sustainable waste and soil management practice, we should also be alert and cautious about the possible adverse impacts it can cause. These limitations should be understood and respected, and care should be taken to identify the threats scientifically to avoid them at all costs.

While being a source of valuable plant nutrients, compost could also be a source of a broad array of contaminants of emerging concern (CECs) which are not completely understood or removed during the composting process (Watteau et al. 2018; European Commission 2003). This group of contaminants includes a variety of substances that are commonly used in daily life such as pharmaceuticals and their breakdown metabolites. Antibiotic-resistant bacteria/genes have also been added to this list recently. CECs are introduced to the environment mainly through wastewater treatment plants, activated sludge, and manure and cause known or suspected adverse ecological and human health effects (Snow et al. 2017; Zuloaga et al. 2012). The agricultural use of sewage sludge/compost and manure as a fertiliser has become one of the most widespread routes for the release of these substances in the environment since it provides an opportunity to recycle plant nutrients and organic matter to the soil for crop production (Zuloaga et al. 2012). In this way, these contaminants can enter the food chain via crop plants and compromise human, animal, and environmental health (Wiechmann et al. 2015).

Plastics and microplastics are also now considered within the category of CECs due to their widespread presence, persistence, and multiple ecotoxicological and ecological hazards that these particles pose to the terrestrial ecosystem (Souza Machado et al. 2018; Avio et al. 2017). Agroecosystems are particularly emphasised as the major entry point for microplastics in the environment via land application of sludge and compost (Rillig 2012). Pharmaceuticals and especially antibiotics are the other groups in CECs which have the potential to enter the environment and cause known or suspected adverse ecological or human health effects (Snow et al. 2017). Globally, antibiotics have drawn considerable attention due to their increasing use and capacity for being a selective pressure for multi-resistant bacteria (Grenni et al. 2018; Caucci et al. 2016). Antibiotics have the potential to affect natural microbial communities after their entry into the environment (Grenni et al. 2018). Like microplastics, antibiotic residues are present in the environment for a while, but the impacts of antibiotics and antibiotic-resistant genes of bacteria are not well-known yet (Bengtsson-Palme et al. 2018; Snow et al. 2017).

The severity and extent of adverse environmental and health impacts posed by these contaminants are generally unknown due to their complex interactions and transformation processes. Thus, the quality of compost has become a subjective term, while the legal framework and standards differ vastly between countries (Hogg et al. 2002). While there are ongoing efforts on improving quality standards for composting, as it can be seen in the case of European Union which now has a 
comprehensive regulatory framework for different types of fertilisers (discussed in case study from Italy in Chap. 9 and from Finland in Chap. 10), it is not the case in many other countries around the world (Pollak and Favoino 2004; European Compost Network 2014). These emerging issues need to be further discussed among policymakers and scientists in the scope of sustainability of organic waste recycling and its application to reflect the current level of knowledge on CECs in regulatory frameworks and quality standards to minimise any potential risk.

\section{The Way Forward}

Compost presents a good example of considering organic waste as a resource rather than a nuisance to be discarded. It is a resource currently "out of place" that needs to be "put in place" for the benefit of the society, the economy, and the environment - the three pillars of sustainability. It provides an opportunity to realise an attractive circular approach which is now widely emphasised for a more efficient use of our limited natural resources. Rather than throwing the organic waste away, we can close the cycle by returning part of it to the land, where it came from.

Increased soil quality, evidenced by higher productivity and soil resilience, presents the most effective testimony to the societal significance of compost. The chapters of this book show that many operational techniques are available now to produce a range of composts of different composition. Citizen participation in collecting and separating waste has been proven effective in several countries. One such example is the Cajicá case in Colombia as presented in Chap. 2. However, the continuation of such systems is all too often subject to local politics and unreliable funding, and this may result in unsustainable systems.

Therefore, the question should be raised as to how this vulnerability of the system can be reduced by establishing a healthy economic basis for the complete compost chain. This can be achieved by demonstrating that the nutrients in compost and increased SOM are economically and environmentally attractive as they produce not only higher but also more reliable crop yields while improving soil biodiversity. This can best be achieved by well-documented case studies, several of which are presented in the chapters of this book. In-depth soil studies of interrelated physical, chemical, and biological processes are quite limited so far, and this needs more attention in the future. It is important to consider the entire chain ranging from waste generation to waste collection/separation to compost formation and finally application to soil. Unfortunately, the emphasis is so far on the first part of the chain: waste collection and compost formation.

We should also recognise some of the operational problems inherent in compost applications such as time lag: additions of compost to soils do deliver nutrients but do not instantly increase the SOM. Continued soil biological activity is needed to incorporate the new organic matter into the soil fabric. This process can take at least several years. Classic research, applying compost in different quantities to different fields and measuring yields, as elaborated in Chap. 5, does, therefore, not provide an 
answer to the attractive long-term perspective of adding compost to soils. This tells us again that we should also invest in field studies, finding examples of land where compost has already been added for long periods, comparing results with similar data for soils where compost has not been applied. Only through this can we show relevant differences. While doing so, we should realise that different soils have different chemical properties and soil moisture regimes, leading to results that will always be site-specific.

The successful application of compost, leading to higher agricultural production and increased soil quality, is a very positive result that farmers can appreciate. Meeting the needs of farmers supports the societal aspect of sustainable development. Applying compost with nutrients means less usage of chemical fertilisers, and this implies possible savings. Such results should convince even the most critical compost users, because usually "money talks" most convincingly.

Once compost is seen by farmers as a crucial element of future soil management, the demand for compost and the demand for organic waste will also increase. When the end users in the agricultural sector, i.e. farmers, become prosperous, the social benefits in the compost chain would eventually take the reverse path, due to an increased demand ensuring that those who work in the waste sector are also economically and socially benefiting from the process. The reverse path can also be beneficial from the capacity development point of view: scientific evidence not only shows that using compost is economically attractive for farmers but also encourages farmers who are already convinced to convince others. Finally, the policy arena should also be addressed making sure that regulatory measures support rather than suppress the proper application of compost, as discussed in Chap. 5 and several others.

\section{References}

ADB. (2011). Toward sustainable municipal organic waste management in South Asia: A guidebook for policy makers and practitioners. Mandaluyong City: Asian Development Bank.

Apostolakis, A., Panakoulia, S., Nikolaidis, N. P., \& Paranychianakis, N. V. (2017). Shifts in soil structure and soil organic matter in a chronosequence of set-aside fields. Soil and Tillage Research, 174, 113-119.

Avio, C. G., Gorbi, S., \& Regoli, F. (2017). Plastics and microplastics in the oceans: From emerging pollutants to emerged threat. Marine Environmental Research, 128, 2-11.

Azim, K., Soudi, B., Boukhari, S., Perissol, C., Roussos, S., \& Thami Alami, I. (2018). Composting parameters and compost quality: A literature review. Organic Agriculture, 8(2), 141-158.

Barker, A. V. (1997). Composition and uses of compost. In Agricultural uses of by-products and wastes, American chemical society 668 (pp. 140-162). Washington, DC: American Chemical Society.

Bastida, F., Selevsek, N., Torres, I. F., Hernández, T., \& García, C. (2015). Soil restoration with organic amendments: Linking cellular functionality and ecosystem processes. Scientific Reports, 5, 15550. 
Bengtsson-Palme, J., Kristiansson, E., \& Larsson, J. D. G. (2018). Environmental factors influencing the development and spread of antibiotic resistance. FEMS Microbiology Reviews, 42(1), 68-80.

Borrelli, P., Robinson, D. A., Fleischer, L. R., Lugato, E., Ballabio, C., Alewell, C., Meusburger, K., Modugno, S., Schütt, B., Ferro, V., \& Bagarell, V. (2017). An assessment of the global impact of 21st century land use change on soil erosion. Nature Communications, 8(1), 2013.

Bouma, J. (2014). Soil science contributions towards sustainable development goals and their implementation: Linking soil functions with ecosystem services. Journal of Plant Nutrition and Soil Science, 177(2), 111-120.

Bouma, J. (2018). The challenge of soil science meeting society's demands in a "post-truth", "factfree" world. Geoderma, 310, 22-28. https://doi.org/10.1016/j.geoderma.2017.09.017. Viewed in May 2019.

Bouma, J. (2019a). How to communicate soil expertise more effectively in the information age when aiming at the UN sustainable development goals. Sand Use and Management, 35(1), 32-38.

Bouma, J. (2019b). Soil security in sustainable development. Soil Systems, 3, 5.

Brändli, R. C., Kupper, T., Bucheli, T. D., Zennegg, M., Huber, S., Ortelli, D., Müller, J., et al. (2007). Organic pollutants in compost and Digestate: Part 2. Polychlorinated dibenzo-pdioxins, and -furans, dioxin-like polychlorinated biphenyls, brominated flame retardants, perfluorinated alkyl substances, pesticides, and other compounds. Journal of Environmental Monitoring, 9(5), 465-472.

Caucci, S., Karkman, A., Cacace, D., Rybicki, M., Timpel, P., Voolaid, V., Gurke, R., Virta, M., \& Berendonk, T. U. (2016). Seasonality of antibiotic prescriptions for outpatients and resistance genes in sewers and wastewater treatment plant outflow. FEMS Microbiology Ecology, 92, fiw060.

Cesarano, G., De Filippis, F., La Storia, A., Scala, F., \& Bonanomi, G. (2017). Organic amendment type and application frequency affect crop yields, soil fertility and microbiome composition. Applied Soil Ecology., 120, 254-264.

Dollhofer, M., \& Zettl, E. (2017). Quality assurance of compost and digestate experiences from Germany. German Environment Agency.

European Commission. (2003). Directorate-general for the environment, and applying compost: Benefits and needs. In Seminar proceedings, Brussels, 22-23 November 2001. Vienna: Federal Ministry of Agriculture, Forestry, Environment and Water Management.

European Compost Network. (2014). European quality assurance scheme for compost and digestate ECN-QAS.

Field, D. J., Morgan, C. I. S., \& Mc Bratney, A. D. (2017). Global soil security. Cham: Springer Publishing.

Grenni, P., Ancona, V., \& Caracciolo, A. B. (2018). Ecological effects of antibiotics on natural ecosystems: A review. Microchemical Journal, 136, 25-39.

Hettiarachchi, H. (2018). Going full circle: Why recycling isn't enough. The Japan Times. https:// www.japantimes.co.jp/opinion/2018/10/15/commentary/japan-commentary/going-full-circlerecycling-isnt-enough/\#.XOaOZYgzY2w. Viewed in May 2019.

Hettiarachchi, H., \& Ardakanian, R. (2016a). Environmental resource management and Nexus approach: Managing water, soil, and waste in the context of global change. Basel: Springer Nature.

Hettiarachchi, H., \& Ardakanian, R. (2016b). Good practice examples of wastewater reuse. Dresden: UNU-FLORES.

Hettiarachchi, H., \& Ardakanian, R. (2018). Safe use of wastewater in agriculture: From concept to implementation. Cham: Springer Nature.

Hettiarachchi, H., Meegoda, J. N., \& Ryu, S. (2018). Organic waste buyback as a viable method to enhance sustainable municipal solid waste management in developing countries. International Journal of Environmental Research and Public Health, 15(11), 2483.

Hogg, D., Barth, J., \& Favoino, E. (2002). Comparison of compost standards within the EU, North America and Australasia. The Waste and Resources Action Programme. 
Initiative 4 pour 1000. (2018). What is the “4 per 1000” Initiative? Initiative « 4 pour 1000 » ecrétariat Exécutif c/o CGIAR System Organization, 1000 av. Agropolis, 34394 Montpellier, France.

Jones, A., et al. (2012). The state of soil in Europe. In A contribution of the JRC to the European Environment Agency's environment state and outlook report. Luxembourg: Publications Office of the European Union.

Kaza, S., Yao, L., Bhada-Tata, P., \& Van Woerden, F. (2018). What a waste 2.0: A global snapshot of solid waste management to 2050. Washington, DC: World Bank Publications.

Keesstra, S. D., Bouma, J., Wallinga, J., Tittonell, P., Smith, P., Cerda, A., Montanarella, L., Quinton, J., Pachepsky, Y., van der Putten, W. H., Bardgett, R. D., Moolenaar, S., Mol, G., \& Fresco, L. O. (2016). The significance of soils and soil science towards realization of the United Nations sustainable development goals. The Soil, 2, 111-128.

Lado, M., Paz, A., \& Ben-Hur, M. (2004). Organic matter and aggregate size interactions in infiltration, seal formation, and soil loss. Soil Science Society of America Journal., 68(3), 935-942.

Martínez-Blanco, J., Lazcano, C., Christensen, T. H., Muñoz, P., Rieradevall, J., Møller, J., Antón, A., \& Boldrin, A. (2013). Compost benefits for agriculture evaluated by life cycle assessment: A review. Agronomy for Sustainable Development, 33(4), 721-732.

Mbuligwe, S. E., Kassenga, G. R., Kaseva, M. E., \& Chaggu, E. J. (2002). Potential and constraints of composting domestic solid waste in developing countries: Findings from a pilot study in Dar Es Salaam, Tanzania. Resources, Conservation and Recycling, 36(1), 45-59.

Onwosi, C. O., Igbokwe, V. C., Odimba, J. N., Eke, I. E., Nwankwoala, M. O., Iroh, I. N., \& Ezeogu, L. I. (2017). Composting technology in waste stabilization: On the methods, challenges and future prospects. Journal of Environmental Management, 190, 140-157.

Oppliger, A., \& Duquenne, P. (2016). Highly contaminated workplaces. In Environmental mycology in public health (pp. 79-105).

Otoo, M., \& Drechsel, P. (2018). Resource recovery from waste: Business models for energy, nutrient and water reuse in low- and middle-income countries. Oxon: Routledge - Earthscan.

Panagos, P., \& Borrelli, P. (2017). Soil erosion in Europe: Current status, challenges and future developments. In All that soil erosion: The global task to conserve our soil resources (pp. 20-21). Soil Environment Center of the Korea.

Pollak, M., \& Favoino, E. (2004). Heavy metals and organic compounds from wastes used as organic fertilisers. Directorate-General for the Environment of the European Commission.

Rillig, M. C. (2012). Microplastic in terrestrial ecosystems and the soil? Environmental Science \& Technology, 46(12), 6453-6454.

Román, P., Martínez, M. M., \& Pantoja, A. (2015). Farmer's compost handbook experiences in Latin America. Santiago: Food and Agriculture Organization of the United Nations (FAO).

Snow, D. D., Cassada, D. A., Larsen, M. L., Mware, N. A., Li, X., D’Alessio, M., Zhang, Y., \& Sallach, J. B. (2017). Detection, occurrence and fate of emerging contaminants in agricultural environments. Water Environment Research, 89(10), 897-920.

Souza, M., de Anderson, A., Kloas, W., Zarfl, C., Hempel, S., \& Rillig, M. C. (2018). Microplastics as an emerging threat to terrestrial ecosystems. Global Change Biology, 24(4), 1405-1416.

Subramanian, B., Hettiarachchi, H., \& Meegoda, J. N. (2019). Crop residue burning in India: Policy challenges and potential solutions. International Journal of Environmental Research and Public Health, 16, 832.

Thanh, T. H., Yabar, H., \& Higano, Y. (2015). Analysis of the environmental benefits of introducing municipal organic waste recovery in Hanoi City, Vietnam. Procedia Environmental Sciences, $28,185-194$.

UN. (2015a). Transforming our world: the 2030 Agenda for Sustainable Development. The resolution adopted by the General Assembly on 25 September 2015. United Nations.

UN. (2015b). The Millennium Development Goals report 2015. New York: United Nations.

UN. (2017). World population prospects: The 2017 revision. United Nations Department of Economic and Social Affairs - Population Division.

UNCCD. (2017). The global land outlook (1st ed.). Bonn: United Nations Convention to Combat Desertification. 
USADA. (2011). Guidance: Compost and vermicompost in organic crop production. In National organic program. Washington, DC: United States Department of Agriculture.

Watteau, F., Dignac, M. F., Bouchard, A., Revallier, A., \& Houot, S. (2018). Microplastic detection in soil amended with municipal solid waste composts as revealed by transmission electronic microscopy and pyrolysis/GC/MS. Frontiers in Sustainable Food Systems, 2.

WCED. (1987). Our common future. In World commission on environment and development. Oxford: Oxford University Press.

Wéry, N. (2014). Bioaerosols from composting facilities a review. Frontiers in Cellular and Infection Microbiology, 4.

Wiechmann, B., Dienemann, C., Kabbe, C., Brandt, S., Vogel, I., \& Roskosch, A. (2015). Sewage sludge management in Germany. German Federal Environmental Agency.

World Bank. (2012). WHAT a WASTE: A global review of solid waste management. In Urban development series, knowledge papers; urban development \& local government unit. Washington, DC: World Bank.

Zuloaga, O., Navarro, P., Bizkarguenaga, E., Iparraguirre, A., Vallejo, A., Olivares, M., \& Prieto, A. (2012, July). Overview of extraction, clean-up and detection techniques for the determination of organic pollutants in sewage sludge: A review. Analytica Chimica Acta, 736, 7-29.

The opinions expressed in this chapter are those of the author(s) and do not necessarily reflect the views of the United Nations University Institute for Integrated Management of Material Fluxes and of Resources (UNU-FLORES), its Board of Directors, or the countries they represent.

Open Access This chapter is licensed under the terms of the Creative Commons Attribution 3.0 IGO license (https://creativecommons.org/licenses/by/3.0/igo/), which permits use, sharing, adaptation, distribution and reproduction in any medium or format, as long as you give appropriate credit to the United Nations University Institute for Integrated Management of Material Fluxes and of Resources (UNU-FLORES), provide a link to the Creative Commons license and indicate if changes were made.

Any dispute related to the use of the works of the United Nations University Institute for Integrated Management of Material Fluxes and of Resources (UNU-FLORES) that cannot be settled amicably shall be submitted to arbitration pursuant to the UNCITRAL rules. The use of the United Nations University Institute for Integrated Management of Material Fluxes and of Resources (UNU-FLORES)'s name for any purpose other than for attribution, and the use of the United Nations University Institute for Integrated Management of Material Fluxes and of Resources (UNU-FLORES)'s logo, shall be subject to a separate written license agreement between the United Nations University Institute for Integrated Management of Material Fluxes and of Resources (UNU-FLORES) and the user and is not authorized as part of this CC-IGO license. Note that the link provided above includes additional terms and conditions of the license.

The images or other third party material in this chapter are included in the chapter's Creative Commons license, unless indicated otherwise in a credit line to the material. If material is not included in the chapter's Creative Commons license and your intended use is not permitted by statutory regulation or exceeds the permitted use, you will need to obtain permission directly from the copyright holder.

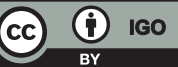

